Journal of Agricultural Sciences

Araştırma Makalesi (Research Article)

\title{
Relationships of Wheat, Dry Bean and Chickpea Yields with Global Climate Change in Suşehri District, Turkey
}

\author{
Ahmet SÜMBÜL ${ }^{* 1}$, Bektaş SÖNMEZ ${ }^{2}$ \\ ${ }^{1}$ Sivas Cumhuriyet University, Suşehri Timur Karabal Vocational Training School, Departman of Plant and \\ Animal Production, 58600, Sivas, Turkey \\ ${ }^{2}$ Sivas Cumhuriyet University, Suşehri Timur Karabal Vocational Training School, Departman of Food \\ Technologies, 58600, Sivas, Turkey \\ ${ }^{1}$ https://orcid.org/0000-0001-9510-0992 ${ }^{2}$ https://orcid.org/0000-0002-8190-409X \\ *Corresponding Author e-mail: asumbul@cumhuriyet.edu.tr, asumbul3188@gmail.com
}

\section{Article Info}

Received: 26.06 .2020

Accepted: 08.10.2021

Online Published: 15.12 .2021

DOI: $10.29133 /$ yyutbd.758727

\section{Keywords}

Chickpea,

Climate change,

Dry bean,

Suşehri,

Wheat.
Abstract: The long-term impact of atmospheric events is defined as climate. Agricultural activities are more affected by climate change since they mostly rely on nature. Agricultural activities may also induce climate change. Therefore, it is valuable to know how agricultural activities are affected by climate change. Therefore, this study was conducted to assess long-term changes in climate and agricultural products and mutual relationships between them in the Suşehri district of Sivas province located in the Kelkit Basin. Climate (air temperature, precipitation, and relative humidity) and yield (crops of wheat, dry bean, and chickpea) data of the 1991 - 2017 period were used. Long-term temporal changes were tested with the nonparametric Mann-Kendall trend test. Relationships were analyzed with the use of the Cochrane-Orcutt estimation regression. The air temperature showed increasing tendency both annually and seasonally, and also had negative effects on wheat yield. Relative humidity showed a positive relationship with the wheat yields both annually and seasonally. Any climate data did not have a significant effect on chickpea and dry bean yields. If the temperature increase continues in the future, negative effects of climate change on agricultural products of the region will be inevitable. It is likely that agriculture in the region will shift to higher altitudes in time. Present findings could be used for the entire Kelkit Basin, which is located in the same climate and geographical zone as Suşehri district.

\section{Suşehri Bölgesinde Buğday, Kuru Fasulye ve Nohut Ürün Verimlerinin Küresel İklim Değișikliği ile İlișkisi}

\section{Makale Bilgileri}

Geliş: 26.06 .2020

Kabul: 08.10.2021

Online Yayinlanma:15.12.2021

DOI: 10.29133 /yyutbd.758727

\section{Anahtar Kelimeler}

Nohut,

İklim değişikliği,

Kuru fasulye,

Suşehri,

Buğday.
Öz: Atmosferde meydana gelen olayların uzun vadeli etkisi iklim olarak tanımlanmaktadır. Tarımsal faaliyetler doğaya bağlı olmaları bakımından iklim değişikliğinden daha fazla etkilenmektedir. Ayrıca tarımsal faaliyetler, iklim değişikliğinden hem etkilenme hem de iklim değiş̧ikliğini etkileme açısından önemli bir konumdadır. Bu nedenle, tarımsal faaliyetlerin iklim değişikliğinden nasıl etkilendiğini bilmek önemlidir. Bu çalışmanın amacı, Türkiye'nin Kelkit Havzası'ndaki Sivas Suşehri'nde iklim ve tarımsal ürün veriminin uzun vadede ki değişimlerini ve birbirleriyle olan ilişkilerini ortaya koymaktır. 1991-2017 yılları arasında ki iklim verileri (hava sıcaklığı, yağış miktarı ve bağıl nem) ve tarımsal ürünlerin (buğday, kuru fasulye ve nohut) verimi kullanılmıştır. Uzun süreli zamansal değişiklikler parametrik olmayan Mann-Kendall trend testi ile test edilmiştir. İlişki testleri ise Cochrane-Orcutt tahmin regresyonu ile analiz 
edilmiştir. Hava sıcaklığı hem yıllık hem de mevsimsel olarak artış eğilimi gösterirken buğday verimi üzerine de olumsuz etki göstermiştir. Ayrıca, bağıl nem, buğday ile hem yıllık hem de mevsimsel olarak pozitif bir ilişki göstermiştir. İklim verilerinin hiçbiri nohut ve kuru fasulye verimi üzerinde anlamlı bir etki göstermemiştir. Eğer gelecekte sıcaklık artışı devam ederse, bölgedeki tarım ürünlerini olumsuz etkilenmesi kaçınılmaz olacaktır. Bölgede yapılan tarımın ise zamanla daha yüksek rakımlara kayması muhtemeldir. Bu çalışmada elde edilen sonuçlar, Suşehri bölgesi de dahil olmak üzere aynı iklim ve coğrafi bölgede bulunan tüm Kelkit Havzasında kullanılabilir.

\section{Introduction}

Climate is defined as the long-term effect of atmospheric events and it is continuously changing over the years (Türkeş et al., 2000). Global climate change is defined as the increase in the average surface temperature of the earth through increasing effects of greenhouse gases including $\mathrm{CO}_{2}$ (carbon dioxide), $\mathrm{CH}_{4}$ (methane), $\mathrm{N}_{2} \mathrm{O}$ (nitrous oxide), $\mathrm{O}_{3}$ (ozone), $\mathrm{CFCs}$ (chlorofluorocarbons), and $\mathrm{H}_{2} \mathrm{O}$ (water vapor), which are encountered mostly as a result of human activities (Dellal and McCarl, 2007). The surface air temperature in the world has increased by approximately $0.85^{\circ} \mathrm{C}$ and the air temperature will be by an average of $1.8-4.0^{\circ} \mathrm{C}$ in 2100 even in the best circumstances if no action is taken (IPCC, 2014). Human activity-induced increase in air temperature could warm up the atmosphere and oceans, change the global water cycle, decrease the snow and glaciers, increase the sea level, change the precipitation amount and pattern and increase the frequency and severity of natural disasters such as drought, flood, hurricanes (Bayraç and Doğan, 2016). Agriculture is more influenced by climate change as compared to the other sectors since it is totally on nature and natural conditions. On the other hand, agriculture is also an important position in terms of both being affected and causing climate change. Agricultural activities such as incorrect land use, excess chemical input (fertilizers, chemical pesticides, insecticides), tillage and livestock operations may increase the release of greenhouse gases, hence inducing climate change.

It is predicted that agricultural production will increase in medium and high latitudes, and yield will decrease in tropical and subtropical regions as a result of increasing global warming (Khasnis and Nettleman, 2005). Moreover, in the air temperature estimations made for 2100, it is thought that an increase of $3{ }^{\circ} \mathrm{C}$ will be the distribution of plant species to $300-400 \mathrm{~km}$ north or $500 \mathrm{~m}$ higher altitudes in temperate regions (Hughes, 2000). Plant species may have difficulties in responding to such changes either by migration or by developing adaptation mechanisms. These troubles can limit the distribution of species and even cause their extinction (Clarke, 2007). It is predicted that these conditions of global climate change will destroy 15-37\% of the species in the world by the year 2050 (Bakkenes et al., 2006; Clarke, 2007).

In order to assess the effects of climate change on agriculture, several research have been conducted on different products in many parts of the world. It was predicted that rain-fed dry-farming lands will shift to the north, and a yield loss of between 10-50\% will be seen (Rosenzweig and Iglesias, 1994; Rosenzweig and Hillel, 1998; McCarl et al., 2001). Climate change may facilitate the weak development of cereals, increase the incidence of disease and pests, resulting in drying of vegetable seedlings, loss of quality and yield, and delayed ripening of fruits (Ogunbameru et al., 2013). These effects could also be encountered in Turkish agricultural fields, such as shortened growth periods, early harvest times, shifting production regions to the central and northern regions, change in production patterns of the regions, and decreased yield and quality (Kuntasal Oğuz, 2012). In Turkey, it was reported that the average yield of wheat, barley, maize, cotton, and sunflower decreased with the effects of climate change (Dellal et al., 2011). Similarly, Gürkan et al. (2017) investigated the effects of climate conditions on the agricultural products of Turkey and reported that the yield of sunflower (for oil) and cotton (seed) decreased across the country. Global climate change will definitely be effective in all regions of Turkey, but the effects of it are expected to vary depending on geographic factors, latitude, and altitudes (Kanber, 2007). It is expected that the air temperature increase will be less in Aegean, Marmara, and Black Sea, but higher in the Mediterranean, Southeastern, and Eastern Anatolia Regions. It is also expected that the decline in precipitations will be higher in the Aegean and Mediterranean, but will not change much in Marmara and Black Sea Regions (Şen, 2013). 
When the studies conducted in the world are evaluated, it was observed that impacts of global climate change on agricultural products, growing conditions of the cultivated plant species varied according to the latitude, elevation, and geographical position of the region to be cultivated. Accordingly, the determination of the effects of climate change on agricultural products in different regions will play a great role in climate change mitigation. Therefore, the present study was conducted to assess long-term changes in climate and agricultural products and mutual relationships between them in the Suşehri district of Sivas province located in the Kelkit Basin. To this purpose, agricultural products widely grown in the region that wheat, dry bean, and chickpea were selected. The long-term variation of the production amount of these products per decare was investigated.

\section{Material and Methods}

\subsection{Study area, climate, and agricultural data}

The study area, Suşehri district of Sivas province is located within the boundaries of the Eastern Black Sea Region (38.09 E $40.16 \mathrm{~N}$ ) of Turkey (Figure 1). The total surface area is $985 \mathrm{~km}^{2}$ and the altitude is approximately 1000 meters. The district has a transitional climate between the temperate climate of the Black Sea Region and the continental climate of Central Anatolia.

Climate data covering the $1991-2017$ period and including air temperature (AT), precipitation (Pr), relative humidity (RH) were obtained from the Turkish State Meteorological Service (https://mevbis.mgm.gov.tr/mevbis) for Suşehri. Climate data were obtained as the monthly mean values for each year, which means 12 values for each parameter of a year. Yields $(\mathrm{kg} / \mathrm{da})$ for wheat, dry bean, and chickpea were obtained from the Turkish Statistical Institute (TUIK) (http://tuik.gov.tr) for Suşehri from January 1991 to December 2017. The selected plant species are commonly grown both in Turkey and the research region. Although the sowing dates of these crops are different, growth, grain filling, and harvest periods take place within the same period in the region.

In agricultural practices of the region, local genotypes are extensively used. However, during the last 5-10 years, certified seeds were started to be used in wheat and chickpea cultivation. Fertilization is carried out in a standard way without soil and leaf analysis. In the last 10 years, irrigation is carried out in wheat, chickpea, and dry bean cultivation of the region (A. Sümbül, unpublished data).

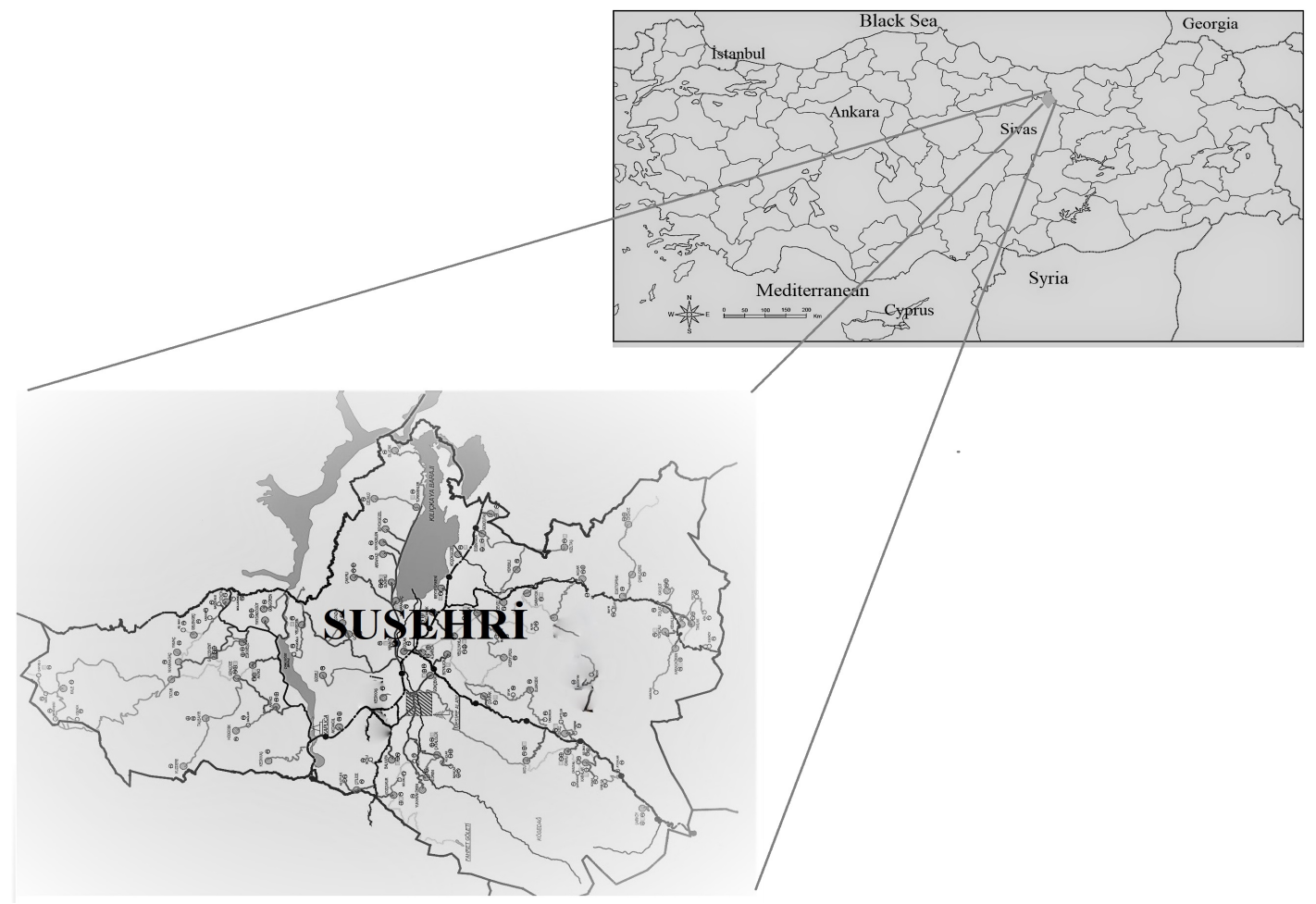

Figure 1. General view of research area. 


\subsection{Statistical analysis}

Tests for trends in climate and agricultural data over the years were performed by means of a nonparametric, nonseasonal Mann-Kendall Trend test (Hipel and McLeod, 1994). It has been widely used to test for randomness against the trend in climatological time series (Zhang et al., 2001; Türkeş et al., 2009; Gümüş et al., 2017). In trend analyses, the Theil-Sen regression slope was used to predict the regression constants based on the Mann-Kendall Trend test and the Kendall correlation coefficients (Sen, 1968). The Mann-Kendall test is based on the calculation of Kendall's tau measure of association between two samples, which itself is based on the ranks of the samples. The null hypothesis is set as "data are independent and randomly ordered". However, the existence of positive autocorrelation in the data increases the probability of detecting trends when actually none exist or vice versa. The presence of autocorrelation in the residuals of the regression models was tested using the Durbin-Watson test. A modified non-parametric trend test that is suitable for autocorrelated data is proposed by Hamed and Rao (1998). It was stated that the accuracy of the modified test in terms of its empirical significance level was found to be superior to that of the original Mann-Kendall trend test without any loss of power. When autocorrelation occurs in the data, the Hamed and Rao method was used for the Mann-Kendall Trend test.

In order to determine the seasonal variations in climate data, the seasonal Mann-Kendall test, not requiring normality of the time series, was used. This test tries to find the trend from one month to another in the overall series rather than finding out whether there is a trend for 12-month seasonal data for the overall series. For this test, all Kendall's tau are firstly calculated for each season. The variance of the statistic is calculated assuming that the series are independent (eg values of one or two months are independent) or dependent, which requires the calculation of a covariance. Seasons were classified as winter (December, January, and February), spring (March, April, and May), summer (June, July, and August), and Autumn (September, October, and November).

In many studies, the relationship between the yields of agricultural products and environmental variables was mostly estimated by ordinary least square test (OLS), which is a traditional regression technique (Zhang et al., 2010; Sarker et al., 2012; Culas and Timsina, 2019). However, the estimate of the OLS technique is not sufficient in many cases, because autocorrelation between variables can violate the assumption that observations are independent, which can lead to a biased estimate of the standard errors of the model parameters and the misleading significance test (Thejll and Schmith, 2005). Such regression models may inadvertently highlight some independent variables that have little or no effect on the dependent variable. It is important to adjust autocorrelation in regression analysis to accurately define the relationship between dependent and independent variables (Thejll and Schmith, 2005). In the case of autocorrelation, the usual linear regression method is invalid because standard errors are not neutral. The Cochrane-Orcutt (CO) estimation is a well-known statistical approach to take autocorrelation into account in the error term of a linear model. The $\mathrm{CO}$ method specifically fixes the effects of serially correlated residuals and yields more accurate regression coefficients than does OLS (Thejll and Schmith, 2005). Therefore, the CO method was used to test the relationship between climate data and agricultural yields. The yield of agricultural products has been tested both annually and seasonally. The seasonal tests were conducted only for the spring and summer seasons. All statistical tests were performed with the use of XLSTAT 2014.5.03 software (Addinsoft, NY, United States).

\section{Results}

The descriptive statistics for annual climate data and agricultural data (yields) of the Susehri district between 1991 - 2017 are given in Table 1.

For 27-years period, mean annual air temperature, precipitation and relative humidity were calculated as $10.36{ }^{\circ} \mathrm{C}, 35.33 \mathrm{~kg} \mathrm{~m}^{-2}$ and $56.43 \%$, respectively. Mean production area was calculated as 143469.2 decares for wheat and 9687.4 decares for bean and 1709.4 decares for chickpea. The average yield was 23626.2 tons for wheat, 1239.1 tons for dry bean and 212.4 tons for chickpea. In addition, mean annual yield for wheat, dry bean and chickpea was respectively calculated as as $171.84 \mathrm{~kg} \mathrm{da}^{-1}$, $128.82 \mathrm{~kg} \mathrm{da}^{-1}$ and $119.92 \mathrm{~kg} \mathrm{da}^{-1}$. 
Table 1. The descriptive statistics for climate and agricultural data

\begin{tabular}{|c|c|c|c|c|c|c|}
\hline \multirow[b]{2}{*}{ Years } & \multicolumn{3}{|c|}{ Climate Data } & \multicolumn{3}{|c|}{ Agricultural Products } \\
\hline & $\begin{array}{c}\text { Air } \\
\text { Temperature } \\
\left({ }^{\circ} \mathrm{C}\right) \\
\end{array}$ & $\begin{array}{c}\text { Relative } \\
\text { Humidity } \\
(\%)\end{array}$ & $\begin{array}{l}\text { Precipitation } \\
\quad\left(\mathrm{kg} \mathrm{m}^{-2}\right)\end{array}$ & $\begin{array}{l}\text { Wheat } \\
\left(\mathrm{kg} \mathrm{da}^{-1}\right)\end{array}$ & $\begin{array}{l}\text { Dry Bean } \\
\left(\mathrm{kg} \mathrm{da}^{-1}\right)\end{array}$ & $\begin{array}{c}\text { Chickpea } \\
\left(\mathrm{kg} \mathrm{da}^{-1}\right)\end{array}$ \\
\hline 1991 & 9.78 & 63.60 & 40.52 & 223 & 200 & 140 \\
\hline 1992 & 7.68 & 66.57 & 38.91 & 230 & 200 & 140 \\
\hline 1993 & 8.81 & 57.80 & 39.05 & 173 & 99 & 121 \\
\hline 1994 & 10.75 & 56.33 & 28.86 & 105 & 72 & 76 \\
\hline 1995 & 10.12 & 61.17 & 41.55 & 153 & 99 & 80 \\
\hline 1996 & 10.86 & 58.30 & 39.03 & 160 & 100 & 100 \\
\hline 1997 & 9.57 & 58.90 & 28.79 & 144 & 102 & 105 \\
\hline 1998 & 10.95 & 54.50 & 42.65 & 128 & 250 & 80 \\
\hline 1999 & 10.86 & 54.70 & 34.56 & 149 & 100 & 133 \\
\hline 2000 & 9.47 & 50.50 & 45.58 & 158 & 104 & 150 \\
\hline 2001 & 11.25 & 46.60 & 31.90 & 149 & 103 & 180 \\
\hline 2002 & 10.17 & 46.87 & 35.83 & 137 & 99 & 126 \\
\hline 2003 & 9.91 & 50.50 & 41.56 & 147 & 107 & 126 \\
\hline 2004 & 9.87 & 46.87 & 35.05 & 145 & 110 & 125 \\
\hline 2005 & 10.26 & 51.27 & 36.39 & 148 & 110 & 125 \\
\hline 2006 & 10.36 & 50.57 & 47.32 & 150 & 120 & 125 \\
\hline 2007 & 10.75 & 48.70 & 32.81 & 121 & 150 & 140 \\
\hline 2008 & 9.84 & 53.57 & 35.22 & 183 & 150 & 140 \\
\hline 2009 & 10.53 & 64.03 & 46.83 & 175 & 160 & 145 \\
\hline 2010 & 12.91 & 57.00 & 23.93 & 175 & 145 & 120 \\
\hline 2011 & 9.44 & 61.37 & 30.05 & 237 & 155 & 125 \\
\hline 2012 & 10.55 & 59.03 & 34.20 & 200 & 145 & 125 \\
\hline 2013 & 10.85 & 55.10 & 22.50 & 225 & 110 & 120 \\
\hline 2014 & 12.03 & 62.77 & 29.48 & 148 & 70 & 101 \\
\hline 2015 & 10.73 & 57.50 & 34.28 & 246 & 110 & 105 \\
\hline 2016 & 10.46 & 53.53 & 36.45 & 225 & 150 & 98 \\
\hline 2017 & 11.08 & 53.87 & 20.53 & 206 & 158 & 86 \\
\hline Mean & 10.36 & 56.43 & 35.33 & 171.85 & 128.81 & 119.89 \\
\hline
\end{tabular}

The temporal variation in climatic data over the years are given Figure 2. The Durbin Watson statistics showed no autocorrelation in the residuals of the regression for air temperature, precipitation and relative humidity $(\mathrm{p}>0.05)$. Annual mean air temperature increased significantly (Kendall's tau $=0.321, \mathrm{p}=0.018$, Sen's slope $=0.051$ ) (Figure 2a) during 1991-2017 period.
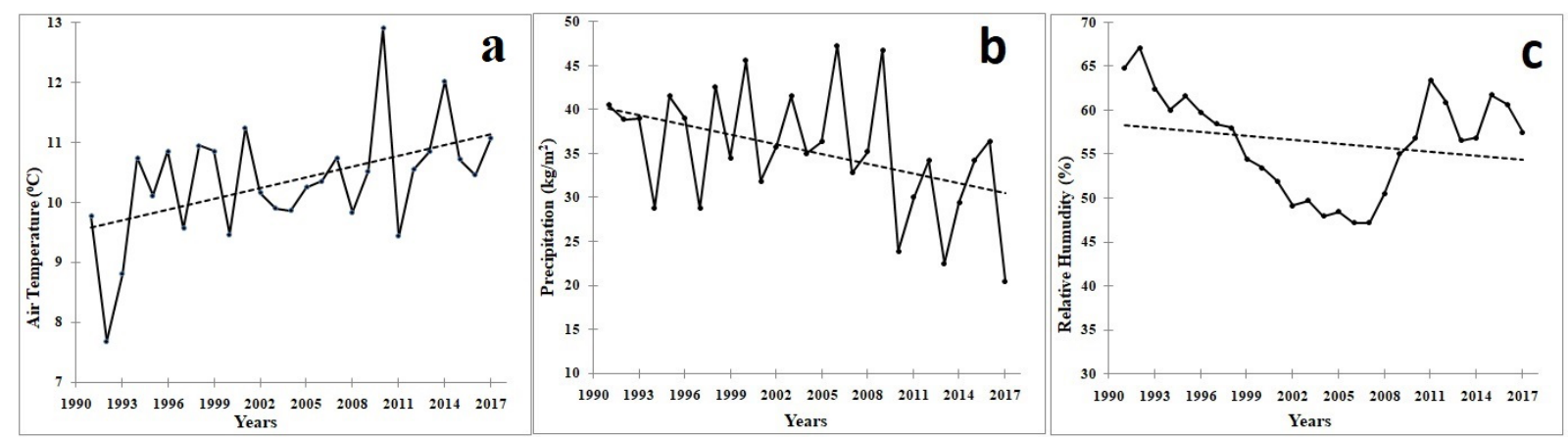

Figure 2. The temporal change in climatic data over the years (a: air temperature, b: precipitation and c: relative humidity) (Black dotted lines are Theil-Sen trend line). 
Increase in annual mean air temperature was approximately 1 degree on average. This increase may be due to the summer season because the mean air temperature in the summer season showed a significant increase (Table 2). Although mean annual precipitation and relative humidity showed decreasing trends, such decreases were not found to be significant ( $p>0.05$ ) (Figure $2 b$ and $c$ ).

Table 2. The Seasonal Mann-Kendall trend test results of the climatic data

\begin{tabular}{ccccccc}
\hline Seasons & \multicolumn{2}{c}{ Temperature } & \multicolumn{2}{c}{ Precipitation amount } & \multicolumn{2}{c}{ Humidity } \\
& Kendall's tau & $\mathrm{p}$ & Kendall's tau & $\mathrm{p}$ & Kendall's tau & $\mathrm{p}$ \\
\hline Winter & 0.139 & 0.433 & $\mathbf{- 0 . 3 1 4}$ & $\mathbf{0 . 0 4 1 *}$ & -0.148 & 0.488 \\
Spring & 0.251 & 0.069 & -0.148 & 0.311 & -0.167 & 0.411 \\
Summer & $\mathbf{0 . 4 1 0}$ & $\mathbf{0 . 0 0 2 *}$ & -0.092 & 0.578 & -0.241 & 0.249 \\
Autumn & 0.202 & 0.144 & -0.037 & 0.853 & -0.028 & 0.928 \\
\hline
\end{tabular}

*Significant at $\mathrm{p} \leq 0.05$.

Also, the seasonal variations in precipitation and relative humidity according to the MannKendall trend test results are given in Table 2. In terms of yields, mean annual wheat and dry bean yields showed an increasing tendency that was not significant ( $>0.05$ ) (Figure 3), while the mean annual chickpea yields showed a decreasing trend that was not significant $(\mathrm{p}>0.05)$ during the 1991-2017 period (Figure 3).
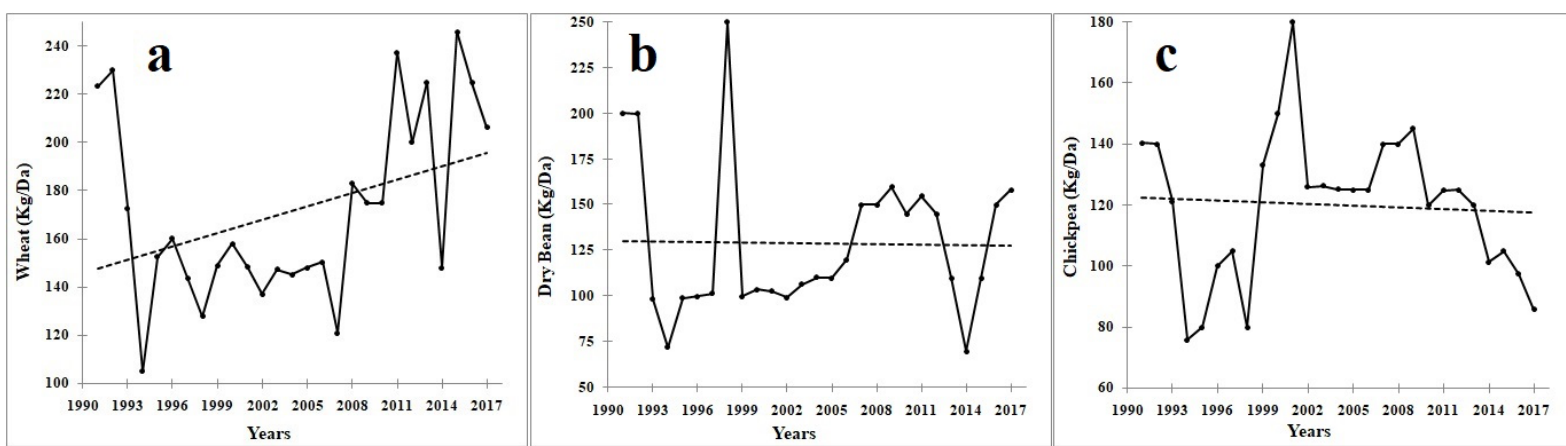

Figure 3. The temporal change in yields over the years (a: wheat, b: dry bean, and c: chickpea) (Black dotted lines are Theil-Sen trend line).

The CO model regression indicated that annual mean dry bean and chickpea yields did not have any significant relationships with any of climatic data over the years (see Table 3 for detail). In contrast, it was found that the wheat yields showed significant relationships with the mean relative humidity and annual mean air temperature (Table 3).

While annual wheat yield showed a positive relationship with relative humidity both annually and seasonally (in spring and summer seasons), it showed a negative relationship with annual mean air temperature over the years. The image of all significant relationships with a $95 \%$ confidence interval is presented in Figure 4. In the multivariate effect of climatic data on agricultural product yields, the chickpea and dry bean yields did not show a significant relationship neither annually nor seasonally $(\mathrm{P}>0.05)$. In contrast, wheat yield showed a significant relationship both annually and seasonally (only in spring). However, the model obtained could explain the wheat yield change at low rates (Adjusted $\mathrm{R}^{2}$ : $0.30, \mathrm{p}=0.012$ for annual, Adjusted $\mathrm{R}^{2}: 0.29, \mathrm{p}=0.013$ for spring season). 
Table 3. The relationships between climate and yield data in the Cochrane-Orcutt model regression (P values of significant relationships are shown in bold)

\begin{tabular}{|c|c|c|c|c|c|c|c|c|c|c|c|c|c|}
\hline \multirow[t]{2}{*}{ Climate } & \multirow[t]{2}{*}{ Seasons } & \multicolumn{3}{|c|}{ Wheat } & \multicolumn{4}{|c|}{ Dry Bean } & \multicolumn{5}{|c|}{ Chickpea } \\
\hline & & $\begin{array}{c}\text { Adjusted } \\
\mathrm{R}^{2}\end{array}$ & $\mathrm{~F}$ & $\mathrm{p}$ & $\mathrm{r}$ & $\begin{array}{c}\text { Adjusted } \\
\mathrm{R}^{2}\end{array}$ & $F$ & $\mathrm{p}$ & $\mathrm{r}$ & $\begin{array}{c}\text { Adjusted } \\
\mathrm{R}^{2}\end{array}$ & $F$ & $\mathrm{p}$ & $r$ \\
\hline \multirow{3}{*}{ 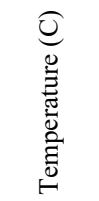 } & Annual & 0.256 & 9.608 & 0.004 & -0.23 & -0.029 & 0.292 & 0.593 & -0.16 & 0.004 & 1.102 & 0.304 & -0.22 \\
\hline & Spring & 0.091 & 3.505 & 0.073 & -0.16 & -0.023 & 0.425 & 0.520 & -0.16 & 0.040 & 2.054 & 0.164 & -0.21 \\
\hline & Summer & 0.095 & 3.623 & 0.069 & -0.05 & -0.016 & 0.598 & 0.446 & 0.13 & 0.005 & 1.124 & 0.299 & -0.01 \\
\hline \multirow{3}{*}{ 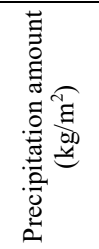 } & Annual & -0.041 & 0.002 & 0.960 & -0.17 & 0.005 & 1.134 & 0.297 & 0.18 & -0.040 & 0.039 & 0.844 & 0.21 \\
\hline & Spring & 0.066 & 2.769 & 0.109 & 0.02 & -0.041 & 0.001 & 0.973 & -0.09 & 0.042 & 2.104 & 0.159 & 0.14 \\
\hline & Summer & -0.008 & 0.799 & 0.380 & 0.17 & -0.032 & 0.222 & 0.641 & 0.15 & -0.008 & 0.801 & 0.379 & -0.01 \\
\hline \multirow{3}{*}{ 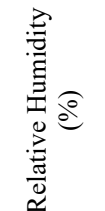 } & Annual & 0.228 & 8.418 & 0.007 & 0.58 & 0.001 & 1.048 & 0.316 & 0.28 & 0.006 & 1.168 & 0.290 & -0.34 \\
\hline & Spring & 0.218 & 7.980 & 0.009 & 0.59 & -0.007 & 0.820 & 0.374 & 0.25 & 0.006 & 1.155 & 0.293 & -0.34 \\
\hline & Summer & 0.247 & 9.208 & 0.005 & 0.49 & -0.008 & 0.795 & 0.381 & 0.30 & -0.041 & 0.001 & 0.974 & -0.23 \\
\hline
\end{tabular}

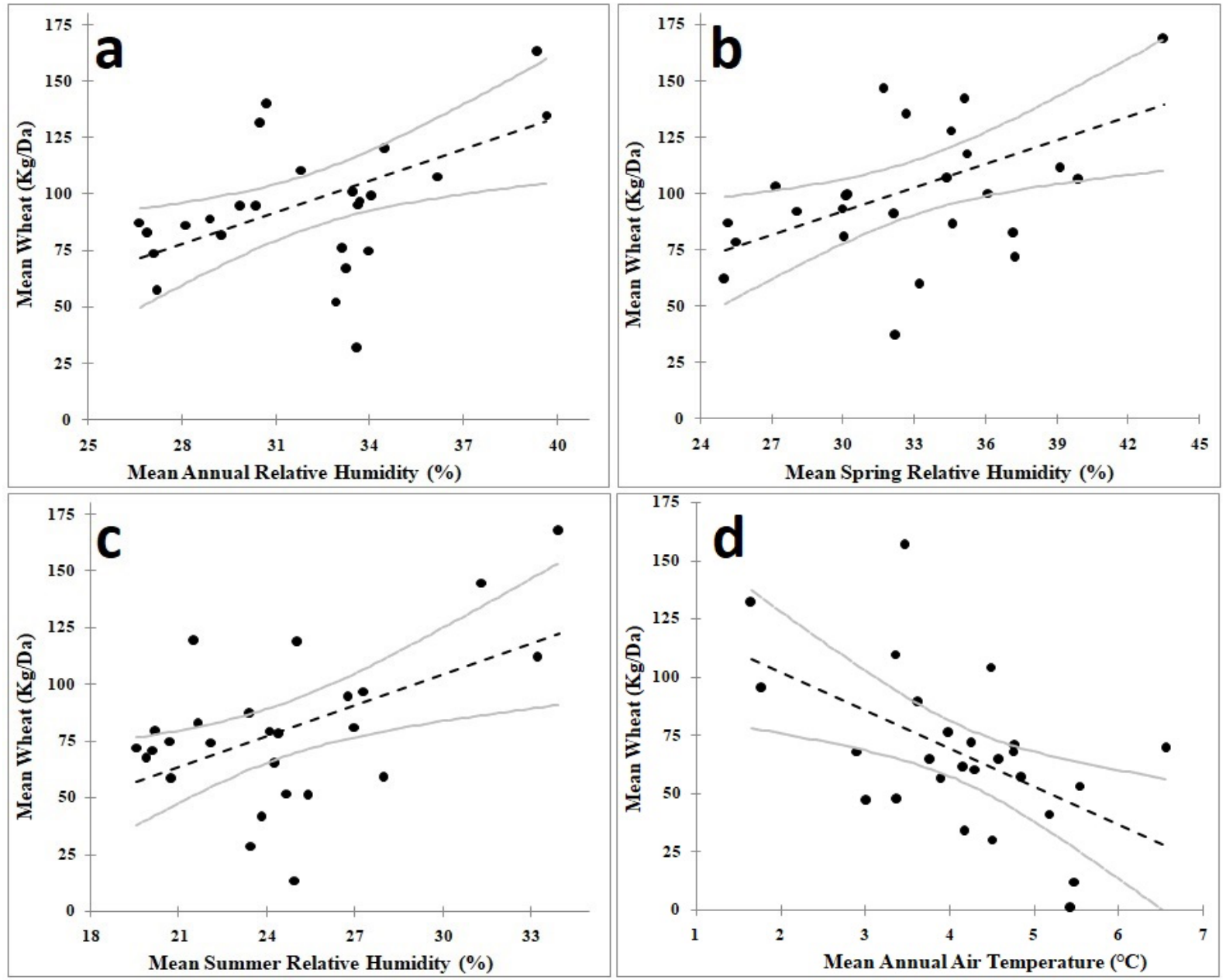

Figure 4. The relationship of wheat yield with relative humidity and annual air temperature (a: annual humidity, b: spring humidity, c: summer humidity, and d: annual air temperature) (gray lines are referred to $95 \%$ confidence interval, and black dotted lines are referred to model lines). 


\section{Discussion and Conclusion}

In climate data, air temperature tended to increase both annually and seasonally, especially in summer. Although present findings were obtained for a single locality, significant increases were reported in air temperatures in different parts of Turkey (Türkeş et al., 2002; Türkeş and Sümer, 2004; Altın et al., 2012; Gümüş et al., 2017). In addition, decreasing long-term precipitation and relative humidity were also reported in various parts of Turkey (Türkeş and Erlat, 2005; Türkeş et al., 2009; Gümüş et al., 2017). In the present study, decreasing relative humidity and precipitation values were also obtained for the present research site.

The impact of global climate change on agricultural products such as wheat, barley, corn, rice, cotton, and sunflower, etc. is being investigated in many regions of the world (Cline, 2007; Pathak and Wassmann, 2007; Dellal et al., 2011). Most of these studies examined the effects of temperature, precipitation, relative humidity, and $\mathrm{CO}_{2}$ intensity. In the present study, wheat yields showed a positive relationship with relative humidity both annually and seasonally (in spring and summer seasons). Wheat yields also showed negative relationships with annual air temperature.

In the Suşehri district, high relative humidity, especially in the spring and summer seasons, provided a high wheat yield. It is important that mean relative humidity should be around $60 \%$ during the development periods of wheat (Süzer, 2007). The relative humidity affects the plant positively by reducing the effect of transpiration and air temperature on the leaves of the plants. Low relative humidity increases the plant transpiration rates, increasing water loss in the plant, and as a result, closes plant stomata. The photosynthesis is prevented and the plant starts to wilt as a result of blocking the gas exchange of the plant, which closes the stomata partially or completely. High relative humidity prevents transpiration in the plant and, by closing the stomata in response, the plant restricts gas exchange (Mott and Parkhurst, 1991; Friend, 1991). As a result, photosynthesis is negatively affected in the plant. In fact, this shows that the relative humidity level below or above the desired limits adversely affects the development of the plant. Uçak et al. (2010) reported that the decrease in the yield and quality of the maize was caused by high temperature and high relative humidity or low temperature and low relative humidity. On the other hand, relative humidity showed an insignificant influence on wheat yield in Pakistan (Ali et al., 2017). Precipitation directly affects the yield during the periods of bolting and grain filling where the development of wheat is fast. Öztürk et al. (2018) stated that high precipitation and relative humidity resulted in an increase in grain filling duration. In other words, the lack of precipitation in bolting and grain filling periods from March to mid-May may cause large losses in yield rates (Soylu and Sade, 2012). In a different perspective, it was estimated that a $1 \%$ increase in precipitation may increase wheat yield as $0.20 \%, 0.12 \%$, and $0.09 \%$ in slight, moderate, and severe drought regions of Turkey, respectively (Doğan and Kan, 2019).

It is estimated that a $2{ }^{\circ} \mathrm{C}$ temperature increase will cause about a $5 \%$ decrease in grain yield, and a $4^{\circ} \mathrm{C}$ increase will cause a $10 \%$ decrease in grain yield worldwide (IPCC, 2007). Çaldağ (2009) reported that there will be significant decreases in wheat yield especially when the air temperature increases more than $3^{\circ} \mathrm{C}$ when combined with the decrease in precipitation. Valizadeh et al. (2014) suggested that the wheat growth period will be shortened with increasing air temperature in Iran, and there will be significant decreases in yield with decreasing rainfall. Yang et al. (2014) reported that the growth periods of wheat in semi-arid regions of Australia will be shortened and yields will decrease as a result of shorter growth times due to extreme air temperatures. Also, the maximum air temperature showed a negative influence on wheat yield in Pakistan, based on a long-term study (Ali et al., 2017). In contrast, the minimum air temperature showed a positive influence on wheat yield in Pakistan (Ali et al., 2017). It was reported in the process-based crop model simulations that a $1{ }^{\circ} \mathrm{C}$ increase in local temperature will decrease wheat yield by $3.3 \%$ (Wilcox and Makowski, 2014). Similarly, it was estimated that a $1 \%$ increase in air temperature may decrease wheat yield by $0.84 \%, 0.43 \%$, and $0.48 \%$ in the slight, moderate, and severe drought regions of Turkey, respectively (Doğan and Kan, 2019). Also, Sayılğan (2016) reported that a $1^{\circ} \mathrm{C}$ increase during the wheat growth period in normal conditions will result in a $5.7 \mathrm{~kg} \mathrm{da}^{-1}$ yield loss in summer wheat. $\mathrm{High} \mathrm{CO}_{2}$ concentration in wheat, which is in the crop category of $\mathrm{C} 3$ plants, increases the process of photosynthesis and suppresses transpiration (Janjua et al., 2014). However, the beneficial effect of $\mathrm{CO}_{2}$ is balanced with the increase in air temperature (Janjua et al., 2014). 
Although wheat yield was negatively affected by air temperature in present study, it did not show any significant decreases during the 1991-2017 period. This indicates that the negative effect of air temperature was tolerated by relative humidity, precipitation, or other complex environmental, or meteorological factors, especially during the development period. Probably, the multiple joint effects of climatic data are more effective on wheat yield. Because the multiple effects of climate data on wheat yield were found to be significant in the annual and seasonal (especially in spring season) models in multivariate regression analysis. However, these models could explain this effect by $30 \%$. The factors that most effective on wheat yield are fertilization and the use of certified seeds. However, $50 \%$ of the increase in wheat yield is associated with fertilization (Sağlam, 2012; Eryılmaz et al., 2017). Although fertilization is widely used in the study region, the yield has tended to decrease. The decrease in wheat yield may have been caused by the effect of the increasing temperature in the study region. In future studies, it may be suggested to investigate the effect of other meteorological variables such as solar radiation, soil temperature, $\mathrm{CO}_{2}$ intensity on agricultural products of Suşehri district. In addition, in the face of global climate change, it is recommended to investigate how the changes in the sowing and harvest dates of wheat according to the increasing trend in temperature and decrease trend in precipitation and relative humidity influence agricultural products in the Suşehri district.

The sowing dates of dry bean and chickpea vary according to regions in Turkey. It is recommended to start the sowing process 5-10 days before the last frosts of spring months (Şehirali, 1988). This date coincides with the last days of March, which is the first month of the spring season in Suşehri. The optimum air temperature for germination is $15-20^{\circ} \mathrm{C}$. Precipitation and high relative humidity negatively affect the flowering period (Şehirali, 1988). Dry bean and chickpea yields did not show a significant relationship with any climate data. After successfully surviving in germination and flowering periods (most of which pass through the spring season), they may have not been affected by the decreasing trend in rainfall and relative humidity and increased trend in air temperature at summer season with the aid of irrigations made by growers.

Various biotic and abiotic factors limit the production potential of legumes. Especially temperature stress is one of the most important factors that negatively influence legumes (Yavas and Ünay, 2018). It is known that fertilization has a positive effect on legumes (Altunkaynak and Ceyhan, 2017; Soysal and Erman, 2020). Fertilization and the other cultural maintenance carried out during the cultivation period may have suppressed the effect of increasing temperature. In addition, the increase in temperature may not have reached a level from which chickpea and bean yields are not negatively influenced. As a matter of fact, chickpeas are known to resist dry conditions (Güler, 2011).

Especially in the last decade, irrigation systems have developed in the region and farmers have been doing irrigation activities against water shortage. It is stated by various researchers that there is an increase in the yield of irrigated products. Kayan (2011) reported that irrigation extended the duration of phenological periods, increasing the plant height, the number of pods in the plant, and the grain yield. In dry beans, it was reported that the drip irrigation method increased grain yield and yield parameters in the Thrace region of Turkey (Şehirali et al., 2005). SSen (2009) predicted that the restrictions in irrigation water will decrease $58 \%$ and $43.4 \%$, in maize's first and second crop yields, respectively. However, it is inevitable that in the future, both the increasingly negative impact of climate change on the groundwater and water system and increasing air temperature and decreasing precipitation and relative humidity will have negative effects on chickpea and dry bean yields of the region. Perhaps in the future, these two agricultural products will have to be cultivated in higher altitudes of the region. It was estimated that the increase of $3^{\circ} \mathrm{C}$ in air temperature will shift the distribution of plant species to $500 \mathrm{~m}$ higher altitudes in temperate regions (Hughes, 2000). In addition to the irrigation systems, possibly $\mathrm{CO}_{2}$ concentration may have a positive effect on dry bean and chickpea yields. It was stated that the $\mathrm{CO}_{2}$ concentration in the atmosphere will increase product yields by $10-50 \%$, especially in legumes (Cutforth et al., 2007) and the other plants (Siqueira et al., 2001; Song et al., 2009).

\section{Acknowledgment}

Preliminary draft of this study was presented as a poster presentation at the Ejons $\mathrm{V}-$ International Congress on Mathematics Engineering, Natural \& Medical ,Sciences Congress in 2018. It was researched on 5 species including different growth and sowing dates in draft 
format. In the new study, number of species was reduced to 3, a new hypothesis was created. After all, manuscript was rewritten using different statistical tests. Authors would like to thank Dr. Erdal AĞLAR who helped to obtain agricultural data.

\section{References}

Ali, S., Liu, Y., Ishaq, M., Shah, T., Ilyas, A., \& Din, I.U. (2017). Climate change and its impact on the yield of major food crops: Evidence from Pakistan. Foods, 6, 39.

Altı, T.B., Barak, B,. \& Altın, B.N. (2012). Change in precipitation amount and temperature amounts over three decades in central Anatolia, Turkey. Atmospheric and Climate Sciences, 02: 107125.

Atunkaynak, A.Ö., \& Ceyhan, E., 2017. Fasulyede (Phaseolus vulgaris L.) Farklı Azot Dozlarının ve Bakteri Aşılamasının Tane Verimi ve Verim Özellikleri Üzerine Etkileri. Selcuk Journal of Agriculture and Food Sciences, 32 (2), 91-98.

Bakkenes, M., Eickhout, B., \& Alkemade, R. (2006). Impacts of different climate stabilisation scenarios on plant species in Europe. Global Environmental Change, 16(1): 19-28.

Bayraç, H.N., \& Doğan, E. (2016). Türkiye'de iklim değişikliğinin tarım sektörü üzerine etkileri. Eskişehir Osman Gazi Üniversitesi İktisadi İdari Bilimler Dergisi, 11(1), 23-48.

Clarke, H. (2007). Conserving biodiversity in the face of climate change. Agenda, 14(2): 157-170.

Cline, W. (2007). Global warming and agriculture impact estimates by country. Center for Global Development Peterson Institute for International Economics, number 4037.

Culas, R., \& Timsina, K.P. (2019). Land use and profitability in wheat production: The Australian wheat-sheep zone. International Journal of Food and Agricultural Economics, 7(2), 107-126.

Çaldağ, B. (2009). Trakya Bölgesi'nin tarımsal meteorolojik özelliklerinin belirlenmesi. (PhD), İstanbul Teknik Üniversitesi, Fen Bilimleri Enstitüsü, İstanbul, Türkiye.

Cutforth, H.W., McGinn, S.M., McPhee, E., \& Miller, P.R. (2007). Adaptation of pulse crops to the changing climate of the Northern great plains. American Society of Agronomy Meetings, 99,1684-1699.

Dellal, İ., \& McCarl, B.A. (2007). İklim Değişikliği ve Tarım: Türkiye için Öngörüler. Uluslararas1 Küresel iklim değiş̧ikliği ve Çevresel Etkileri Konferansı, KOSKİ, Konya.

Dellal, İ., McCarl, B.A., \& Butt, T. (2011). The economic assessment of climate change on Turkish agriculture. Journal of Environmental Protection and Ecology, Vol:12, No:1, 376- 385.

Doğan, H.G., \& Kan, A. (2019). The effect of precipitation amount and temperature on wheat yield in Turkey: a panel FMOLS and panel VECM approach. Environment, Development and Sustainability, 21, 447-460.

Eryılmaz Açıkgöz F., Adiloğlu, S., Solmaz, Y., \& Adiloğlu, A., 2017. The Influence of potassium fertilizer practices on some macro and micro nutrient element ingredient of rocket (Eruca vesicaria subsp. sativa) plant. Oxidation Communications, 40 (3): 1209- 1218.

Friend, A.D. (1991). Use of a model of photosynthesis and leaf microenvironment to predict optimal stomatal conductance and leaf nitrogen partitioning. Plant, Cell and Environment 14, 895-905.

Güler, İ.E., 2011. Erzurum Yöresinde Nohut Tarımının Mekanizasyon Sorunları ve Çözüm Önerileri. Iğdır University Journal of the Institute of Science and Technology, 1(4): 91-98.

Gümüş, V., Soydan, N.G., Şimşek, O., Algın, H.M., Aköz, M.S., \& Yenigun, K. (2017). Seasonal and annual trend analysis of meteorological data in Sanliurfa, Turkey. European Water 59, 131-136.

Gürkan, H., Bayraktar, N., \& Bulut, H. (2017). İklim değişikliği nedeniyle artan kuraklığın ayçiçeği ve pamuk verimi üzerine etkileri. KSÜ Doğa Bilimleri Dergisi, 20 (Özel Say1), 216-221.

Hamed, K.H., \& Rao, A.R. (1998). A modified Mann-Kendall trend test for auto correlated data. Journal of Hydrology, 204: 182-196.

Hipel, K.W., \& McLeod, A.I. (1994). Time series modeling of water resources and environmental systems. Elsevier, Amsterdam, The Netherlands.

Hughes, L. (2000). Biological consequences of global warming: is the signal already apparent. Trends in Ecology and Evolution, 15(2): 56-61.

IPCC. (2007). Climate change 2007: impacts, adaptation and vulnerability, Contribution of Working Group II (AR4). Cambridge: Cambridge University Press. 
IPCC. (2014), The fifth assessment report (AR5). The Intergovernmental Panel on Climate Change, Geneva, Switzerland,

Janjua, P.Z., Samad, G., \& Khan, N. (2014). Climate change and wheat production in Pakistan: An autoregressive distributed lag approach. NJAS-Wagening. J. Life Sci., 68, 13-19.

Kanber, R., Kapur, B., Ünlü, M., Tekin, S., \& Koç, L. (2007). A new approach to evaluation of climatic change effect on agricultural production system: ICCP Project. Pro-ceedings TMMOB 2nd National Conference on Water Politics, Ankara, 83-94.

Kayan, N. (2011). Farklı gelişme dönemlerinde uygulanan sulamanın bazı nohut (Cicer arietinum L.) çeşitlerinde fenolojik özellikler ve verime etkisi, Tarla Bitkileri Merkez Araştırma Enstitüsü Dergisi, 20 (2): 24-32.

Khasnis, A.A., \& Nettleman, M.D. (2005). Global warming and infectious disease. Archives of Medical Research, 36: 689-696.

Kuntasal Oğuz, Ö. (2012). Impact of climate change in Turkey: observations and projections, enabling acilvities for the preparation of Turkey's second national communication to The UNFCC, Ankara.

McCarl, B., Adams, R.M., \& Hurd, B.H. (2001). Global climate change and its impact on agriculture. Texas A\&M University, Agricultural Economis Department, Course Notes, USA.

Mott, K.A., \& Parkurst, D.F. (1991). Stomatal response to humidity in air and helox. Plant, Cell and Environment, 14, 509-515,

Ogunbameru, B.O., Mustapha, S.B., \& Idrisa, Y.L. (2013). Capacity building for climate change. Uluslararası Katılımlı 2. İklim Değişimi Ve Tarım Etkileşimi Çalıştayı, 08-09 Kasım, Şanlıurfa.

Özdoğan, M. (2011). Modeling the impacts of climate change on wheat yields in Northwestern Turkey. Agriculture, Ecosystems and Environment, 141, 1-12.

Öztürk, İ., Kahraman, T., Avcı, R., Girgin, V.Ç., Şili, Ş., Kılıı̧, T.H., Tülek, A., \& Tuna, B. (2018). Effect of the rainfall and humidity at various growth stage on yield and quality in bread wheat (Triticum aestivum L.) cultivars. Agriculture \& Food, 6, 26-36.

Pathak, H., \& Wassmann, R. (2007). Introducing greenhouse gas mitigation as a development objective in rice-based agriculture: I. generation of technical coefficients. Agricultural Systems, 94:807825.

Rosenzweig, C., \& Iglesias, A. (1994) Implications of climate change for interrnational agriculture: crop modeling study. U.S. Environmental Protection Agency, EPA 230-B-94-003, Climate Change Division, Washington DC.

Rosenzweig, C., \& Hillel, D. (1998), Climate change and the global harvest: potential impacts of the greenhouse effect on agriculture. Oxford University Press, New York.

Sağlam, M.T. 2012. Gübreler ve gübreleme. Namık Kemal Üniversitesi, Ziraat Fakültesi, Yayın No: 14, Ders Kitabı No: 6, 370s, Tekirdağ.

Sarker, M.A.R., Alam, K., \& Gow, J. (2012). Exploring the relationship between climate change and rice yield in Bangladesh: an analysis of time series data. Agriculture System, 112, 11-16.

Sayılğan, Ç. (2016). Küresel sıcaklık artışının buğdayda beklenen etkileri ve yüksek sıcaklığa toleranslılı̆̆ın fizyolojik göstergeleri. Yüzüncü Yıl Üniversitesi Tarım Bilimleri Dergisi, 26(3): 439-447.

Sen, P.K. (1968). Estimates of regression coefficient based on Kendall's tau. J Am Stat Assoc 63(324):1379-1389.

Siqueira, O.J.F., Steinmetz, W.S., Salles, L.A.B., \& Fernandes, J.M. (2001). Efeitos potenciais das mudanças climáticas na agricultura brasileira e estratégias adaptativas para algumas culturas. In: mudanças climatıcas globais E A agropecuaria brasileira, 1., jaguariuna, proceedings. jaguariuna: Embrapa Meio Ambiente,. p.33-64.

Song, Y., Linderholm, H.W., Chen, D., \& Walther, A. (2009). Trends of the thermal growing season in China, 1951-2007. International Journal of Climatology, 30:33-43.

Soylu, S., Sade, B. (2012). İklim değişikliğinin tarımsal ürünlere etkisi üzerine bir araştırma projesi. Mevlana Kalkınma Ajansı, Konya.

Soysal, S., Erman, M., 2020. Siirt Ekolojik Koşullarında Mikrobiyolojik Ve İnorganik Gübrelemenin Nohut (Cicer arietinum L.)'un Verim, Verim Öğeleri Ve Nodülasyonu Üzerine Etkilerinin Araştırılması. ISPEC Journal of Agriculturre Sciences 4(3),649-670.

Süzer, S. (2007). Buğday Tarımı ve Önemi. Hasad Bitkisel Üretim Dergisi. 23:64-68. 
Şehirali, S. (1988). Yemeklik Tane Baklagiller, Ankara Üniversitesi Ziraat Fakültesi Yayınları 1089, Ankara.

Şehirali S, Erdem T, Erdem Y, Kenar D (2005). Damla sulama yöntemi ile sulanan fasulyenin (Phaseolus vulgaris L.) su kullanım özellikleri, Tarım Bilimleri Dergisi, 11 (2) 212-216.

Şen, B. (2009). Bölgesel iklim modelleri kullanılarak Çukurova yöresinde iklim değişikliğinin 1. ve 2. ürün misır verimine olası etkilerinin belirlenmesi. (PhD), Çukurova Üniversitesi, Fen Bilimleri Enstitüsü, Adana, Türkiye.

Şen, Ö.L. (2013). Türkiye'de iklim değişikliğinin bütünsel resmi. III. Türkiye İklim Değişikliği Kongresi, TIKKDEK 2013 3-5 Haziran 2013, 2-7.

Thej1l, P., \& Schmith, T. (2005). Limitations on regression analysis due to serially correlated residuals: Application to climate reconstruction from proxies. Journal of Geophysical Research 110, D18103.

Türkeş, M., Sümer, U.M. \& Çetiner, G. (2000). Küresel iklim değişikliği ve olas1 etkileri. Çevre Bakanlığı, Birleşmiş Milletler İklim Değişikliği Çerçeve Sözleşmesi Seminer Notları (13 Nisan 2000, İstanbul Sanayi Odas1), 7-24, Ankara.

Türkeş, M., Sümer, U.M., \& Kılıç, G. (2002). Persistence and periodicity in the precipitation amount series of Turkey and associations with $500 \mathrm{hPa}$ geopotential heights. Climate Research 21:598.

Türkeş, M., \& Sümer, U.M. (2004). Spatial and temporal patterns of trends and variability in diurnal temperature ranges of Turkey. Theoretical and Applied Climatology, 77:195-227.

Türkeş, M., \& Erlat, E. (2005). Climatologic responses of winter precipitation amount in Turkey to variability the North Atlantic Oscillation during the period 1930-2001. Theoretical and Applied Climatology, 81:45-69.

Türkeş, M., Koç, T., \& Saris, F. (2009). Spatio temporal variability of precipitation amount total series over Turkey. International Journal of Climatology, 29:1056-1074.

Uçak, A.B., Ertek, A., Güllü, M., Aykanat, S., \& Akyol, A. (2010). Bazı iklim parametrelerinin Çukurova' da yetiştirilen mısır bitkisi verim ve kalitesine etkileri. Gazi Osmanpaşa Üniversitesi, Ziraat Fakültesi Dergisi, 27(1), 9-19.

Valizadeh, J., Ziaei, S.M., \& Mazloumzadeh, S.M. (2014). Assessing climate change impacts on wheat production (a case study). Journal of the Saudi Society of Agricultural Sciences. Volume 13, Issue 2, June 2014, Pages 107-115.

Yavaş, İ., \& Ünay, A., 2018. Baklagillerde Kök, Nodül Oluşumu ve Azot Fiksasyonu Üzerine Bazı Küresel İklim Değişikliği Parametrelerinin Etkisi. Uluslararası Tarım ve Yaban Hayatı Bilimleri Dergisi, 4(2): $270-278$.

Yang, Y., Liu, D.L., Anwar, M.R., Zuo, H., \& Yang, Y. (2014). Impact of future climate change on wheat production in relation to plant-available water capacity in a semiarid environment. Theoretical and Applied Climatology 115:391-410.

Zhang, X., Harvey, K.D., Hogg, W.D., \& Yuzyk, T.R. (2001), Trends in Canadian streamflow. Water Resources Resarch, 37( 4), 987-998.

Zhang, L., Lei, L., \& Yan, D. (2010). Comparison of two regression models for predicting crop yield. IEEE International Geoscience and Remote Sensing Symposium, Honolulu, HI, 2010, pp. 15211524.

Wilcox, J., Makowski, D.A. (2014). Meta-analysis of the predicted effects of climate change on wheat yields using simulation studies. Field Crop Resarch 156, 180-190. 